\begin{tabular}{|c|c|c|c|}
\hline Article Info & RESEARCH ARTICLE & ARAŞTIRMA MAKALESİ & \\
\hline Title of Article & \multicolumn{2}{|c|}{$\begin{array}{c}\text { The Effect of Place Attachment on Tourism } \\
\text { Strategies: Amasya Example }\end{array}$} & \\
\hline $\begin{array}{l}\text { Corresponding } \\
\text { Author }\end{array}$ & \multicolumn{2}{|c|}{$\begin{array}{l}\text { Aslı ALTANLAR } \\
\text { Amasya Üniversitesi, Mimarlık Fakültesi, Şehir ve Bölge Planlama Bölümü, } \\
\text { asli.altanlar@amasya.edu.tr }\end{array}$} & \\
\hline $\begin{array}{l}\text { Received Date } \\
\text { Accepted Date }\end{array}$ & \multicolumn{2}{|l|}{$\begin{array}{l}06.01 .2021 \\
08.04 .2021 \\
\end{array}$} & \\
\hline Author / Authors & Asli ALTANLAR & ORCID: 0000-0002-7168-1857 & \\
\hline How to Cite & \multicolumn{2}{|c|}{$\begin{array}{l}\text { Altanlar, A. (2021). Turizm Stratejilerinin Yere Bağlılık Üzerindeki Etkisi: Amasya } \\
\text { Örneği, Kent Akademisi, Volume, 14, Issue 1, Pages, 199-213. }\end{array}$} & $\begin{array}{l}\text { Kent Akademisi } \\
\text { Urban Academy }\end{array}$ \\
\hline
\end{tabular}

\title{
Yere Bağlılığın Turizm Stratejileri Üzerindeki Etkisi: Amasya Örneği
}

\begin{abstract}
:
This study aims to examine the relationship between the effect of residents' place attachment on tourism, resident support for tourism development and their behavioral attitude towards sustainable tourism policies. Within the framework of this study, field research was conducted in ten neighborhoods in the city of Amasya with traditional neighborhood texture in 2017. 460 people participated in the study. The participants were selected by simple random sampling and they were asked to complete a survey aimed to measure all three aspects. In order to exhibit the relationship between place attachment and tourism, principal components analysis, multiple regression analysis, spearman correlation analysis, and kruskal wallis analysis were applied. As per the analyses, it was determined that the components that define place attachment are place dependency and social attachment; residents with higher place attachment are more positive towards the development of tourism and the more satisfaction residents have towards tourism-oriented strategies, the more they have social attachment and place dependency. Finally, the findings indicate that a tourism scenario can be sustainable within a framework that strengthens the place attachment of residents living in historical areas and traditional neighborhoods and one that does not contradict with the regional scales and overall identity.
\end{abstract}

KEYWORDS: Place Attachment, Place Identity, Tourism Strategy, Tourism, Support for tourism development, Tourism's Effects. 
ÖZ:

$\mathrm{Bu}$ çalışma mahalle sakinlerinin yere bağlllıklarının turizmin etkileri, turizm gelişimini destekleme niyetleri ile sürüdülebilir turizm politikalarına karşı davranışsal tutumları arasındaki ilişkiyi incelenmeyi amaçlamaktadır. Bu amaçla alan araştırması 2017 yılında Amasya ilinde yer alan ve geleneksel mahalle dokusuna sahip olan on mahallede gerçekleştirilmiştir. Araştırmaya 460 kişi katılmıştır. Basit rastlantısal örnekleme yoluyla seçilen tüm katılımcılara her üç boyutu ölçmeye yönelik anket soruları uygulanmıştır. Yere bağlılık ve turizm stratejileri arasındaki ilişkinin ortaya konulması için temel bileşenler analizi, çoklu regresyon analizi, spearman korelasyon ve kruskal wallis analizleri uygulanmıştır. Yapılan analizler sonucunda yere bağl1lı̆̆ belirleyen bileşenlerin yere bağımlılık ve sosyal bağlılık boyutları olduğu; yere bağl1lıkları güçlü olan yerel sakinlerin turizm gelişimini olumlu karşıladıkları; yerel sakinlerin turizm odaklı stratejilere yönelik memnuniyetleri arttıkça sosyal bağlılıkları ve yere bağımlılıklarının da arttığı tespit edilmiştir. Sonuç olarak elde edilen bulgular tarihi çevre ve geleneksel mahallelerdeki yerel sakinlerin yere bağlılığını güçlendiren, bölgenin ölçeği ve genel kimliği ile çelişmeyecek bir yapılanma içinde bir turizm senaryosunun sürdürülebilir olacağını ortaya koymaktadır.

ANAHTAR KELIMELER: Yere Bağlılık, Yer Kimliği, Turizm Stratejisi, Turizm Desteği, Turizm Etkileri.

\section{"Yere bağlılığın Turizm Stratejileri Üzerindeki Etkisi: Amasya Örneği”"}

\section{GíRiş:}

Turizm odaklı kentsel geliştirme amacıyla tarihsel/geleneksel kent dokusunda turizm faaliyetlerinin gerçekleştirilmesi için öngörülen fonksiyon değişiklikleri kültürel miras açısından çekiciliği olan geleneksel mahallelerin hem mekânsal hem de sosyal açıdan zarar görmesine ve kentin farklı bölgeleri arasındaki dengenin, kentsel işlevler açıdan değişmesine neden olabilmektedir (Bolzoni 2014). Turizm sektöründe ortaya çıkan olası aşırı ve kontrolsüz büyüme konut fonksiyonunun neredeyse tamamıyla dışlanmasına ve mahallenin kimliği ile uyuşmayan bir turizm tesisi profiline dönüşmesine neden olabilmektedir. Tarihi kent mekanında ortaya çıkan bu türlü dönüşümler spekülatif amaçlı hareketleri tetiklemekte ve bu bunun bir sonucu olarak alanda kentsel turizme yönelik ticari bir soylulaştırma gerçekleşebilmektedir (Türkün 2015). Ticari ve rekreasyonel arazi kullanımların arasında meydana gelen bu dönüşüm, mahallenin kimliği ve yerin anlamının değişmesine neden olduğu gibi aynı zamanda gündelik rutinler ve aidiyet duygusu üzerinde de büyük ölçüde etkili olmaktadır. Meydana gelen dönüşümden mahalle ve kent sakinlerinin etkilenmediği durumlarda bile kentsel aidiyet duygusunda bir azalma olabilmektedir (Bolzoni 2013). Bu nedenle turizmin sadece ekonomik sonuçlarının incelenmesi kamu yararı açısından oldukça yanıltıcı sonuçlar elde edilmesine neden olmaktadır. Özellikle eski kent merkezlerinin dinlence ve tüketim yerleri açısından potansiyel olarak görülmesi, ticari ve konutsal soylulaştırmaya neden olarak kamusal kaynakların meşru tahsisi ve kamusal alan kullanımı ile ilgili yeni gerilimlere neden olabilmektedir (Bolzoni 2014). Söz konusu bu dönüşümler sadece yörenin özgünlük değerini olumsuz yönde etkilememekte, insanların yer kimliklerini ve yere bağlılıklarını da sarsmaktadır. Bu nedenle bu çalışma mahalle sakinlerinin yere bağl1lıklarının turizm gelişimini destekleme niyeti ile sürdürülebilir turizm politikalarına karşı davranışsal tutumları arasındaki ilişkiyi incelemeyi amaçlamaktadır. $\mathrm{Bu}$ amaçla belirlenen araştırma soruları aşağıda maddeler halinde verilmiştir:

1. Yerel sakinlerin yere bağlılıkları ile turizmin desteği arasında anlamlı bir farklılık var mıdır?

2. Yerel sakinlerin yere bağlılıkları ile turizm gelişiminin genel etkilerini algılamaları arasında anlamlı bir farklılık var midır?

3. Yerel sakinlerin yere bağlılıkları ile sürdürülebilir turizm odaklı stratejilere bakış açıları arasında anlamlı bir ilişki var mıdır? Varsa ilişkinin yönü ve şiddeti nedir? 


\section{1. Çevre Psikolojisi Açısından Yere Bağlılık ve Yer Kimliği}

Belirli bir yerle bir tür bağ ya da bağlantı anlamına gelen yere bağlılık kavramı çevre psikolojisi alanında çalışlan önemli bir konudur. Bu alandaki araştırmacılar, bireysel yer bağını kavramsallaştırmak, anlamak ve ölçmek için çok sayıda çalışma yürütmüştür. Yerin anlam akışının anlaşılabilmesi için insanların fiziksel ortamları ile sosyal çevreleri arasında sürekli devam eden etkileşim sürecinin anlaşılması gerekmektedir (Yılmaz Çakmak 2013). Önceki çalışmalar, yere bağlılığın kavramsallaştırılması ve belirleyicileri üzerinde yoğunlaşmıştır (Chen vd, 2014). Bazı araştırmacılar yere bağlıllı̆ı çok boyutlu bir değişken olarak görürken (Chen 2018) bazı araştırmacılar yere bağlllığı tek boyutlu bir değişken olarak kabul etmektedir (Stylidis 2017; Tournois ve Djeric 2019; Shen vd, 2019). Son araştırmalarda yere bağlılık, yer kimliği ve yer bağımlılığını içeren iki boyutlu bir değişken olarak çevre psikolojisi ve turizm yönetimi alanlarında yaygın olarak kabul görmektedir (Kyle vd, 2005; Chen vd, 2014).

Yere bağlılık, insan-mekan bağının farklı yönlerini içeren ve bir yere atıfta bulunarak duyguların, bilgi ve inançların, davranışların ve eylemlerin karşılıklı etkileşimini içeren çok yönlü ve karmaşık bir olgudur (Rollero ve Piccoli, 2010). Başka bir deyişle yere bağlılık kavramı, bireyin ya da toplulukların kavrayış, inanç, bakış açısı ve düşüncelerinin de etkisiyle fiziksel ve sosyal çevreyi deneyimlemesi sonucu o yere verdiği anlamlardan meydana gelmektedir (Brown vd, 2003; Kyle vd, 2005). Hidalgo ve Hernandez (2001) yere bağlılığı insanların kendilerini rahat ve güvende hissettikleri ve kalma eğilimlerinin olduğu yerler ile ilgili kurdukları duygusal bağ olarak tanımlamaktadır. Vorkin ve Reise (2001) yere bağl1lığı, bireylerin bir yere verdiği değerlerin ölçüsü, bireyler ve yaşadıkları çevreler arasındaki güçlü çağrışım ve bireyin bir yere ilişkin fonksiyonel hislerini içeren duygusal ya da sembolik çağrışımları olarak ifade etmektedir. Tanımlardan da anlaşıldığı üzere yere bağlılık, bireyin kendini ifade etme, aktarma, öngörülebilirlik ve kontrol ihtiyacının giderilmesi ve bireyler, gruplar, topluluklar ve kültürler düzeyinde kimlik oluşturma ihtiyacının karşılanması gibi işlevleri sağlamanın (Göregenli 2010) yanısıra bireyin ihtiyaç duyduğu durağanlık, güven, kontrol hislerini de desteklemektedir (Lewicka 2005). Yere bağlılık kavramı daha önce de bahsedildiği üzere çok sayıda araştırmada bireyin yaşadığı fiziksel dünya hakkındaki genel kavrayışından oluşan, kişinin öz kimliğinin bir alt yapısı olan yer kimliği ile ilişkilendirilmektedir (Rollero ve Piccoli 2010).

Yer kimliği, kişinin kendi kimliğinin, bilinçli ve bilinçsiz düşünceler, inançlar, tercihler, duygular, değer yargıları, amaçlar, davranışlar ve beceriler gibi birçok yanını kapsayan kompleks örüntüsünün fiziksel çevre boyutu ile tanımlamasını ifade etmektedir (Kyle vd, 2004). Başka bir ifadeyle yer kimliği, bir yerin bir birey için sahip olduğu anlamı ifade ederken, yere bağlılık bir kişinin hedeflerini ve planlanan faaliyetlerini desteklemede bir yerin önemini ortaya koymaktadır (Stylidis 2017). Literatürde yere bağlılık ve yer kimliği arasındaki ilişkiye dair en az dört farklı bakış açısı bulunmaktadır: (1) aynı kavram olarak kabul edilebilirler; (2) yere bağlılık yer kimliğinin bir bileşeni olabilir; (3) yer kimliği, yere bağlılığın bir bileşeni olabilir; (4) her iki kavram da sadece üst sıralı bir kavramın boyutlarıdır (Rollero ve Piccoli 2010). Herna'ndez ve arkadaşları (2007) ise bu bakış açılarına ek olarak yere bağlılık ve yer kimliği kavramlarının, birbirleri ile bağlantılı olsalar dahi, yerlerle ilişkilendirmenin iki farklı yolu olduğunu ve farklı şekilde değerlendirmeleri gerektiğini ileri sürmektedir (Herna'ndez vd, 2007). Bu düşünceleri takiben, bireyler ve çevreleri arasındaki ilişkinin birbiriyle bağlantılı ama farklı iki yönü olduğunu söylemek mümkündür: duyuşsal bir boyut, yani yerlere olan duygusal bağ (yere bağll1ık) ve fiziksel bir alanın bir üyesi olarak kendilik hakkındaki bilişlerle ilgili bilişsel bir boyut (yer kimliği) (Rollero ve Piccoli 2010).

Önceki çalışmalar bir yerle duygusal bir bağın gelişmesiyle ilgili olarak, sosyal bağların etkisini de ortaya koymaktadır (Fried 2000; Gursoy ve Rutherford 2004; Lewicka 2005). Fried (2000) göre, bağlanma insanların yerel iliş̧kileri deneyimlemenin daha derin bir anlamı ve ilişkisel etkileşim yerleriyle anlaşılabilir. Bu anlayış doğrultusunda Pretty ve arkadaşları (2003) yaşadıkları çevrede var olan arkadaşlık ilişkilerinin yere bağlılık kavramının kurucu bir yönü olduğunu ileri sürmüştür (Pretty vd, 2003’ten akt. Rollero ve Piccoli 2010). Örneğin Ramkissoon ve arkadaşları (2013) yere bağlılı̆̆ belirleyen bileşenleri yer bağımlılığı, yer kimliği, yer duygusu ve sosyal bağlılık olarak kavramsallaştırmış ve bağlanma ve yer memnuniyeti arasında pozitif yönlü bir ilişki olduğunu bulmuşlardır. Bu çalışmalarda sosyal bağlar, komşuluk ilişkileri ve mahalledeki arkadaş sayısı, tesadüfi sosyal karşılaşmalar, mahalledeki sosyal aktivitelere katılım ve bu aktivitelerin sıklığı, mahalle sakinleriyle olan ilişkilerin yüzeysellik ve derinlik açısından özellikleri gibi çok çeşitli şekillerde ele alınabilmektedir (Göregenli vd, 2014). Yerel ilişkilerdeki yoğunluk arttıkça, kendini tamamen evinde hisseden insanların oranı da o kadar büyük olmaktadır. Nedensel bir yaklaşım benimsendiğinde, yere bağlılık ile sosyal bağlar arasındaki ilişkinin etki yönü her zaman aynı değildir. Lewicka (2005) mekana bağlanmayı, komşuluk bağlarının güçlü ve olumlu bir ön göstergesi olarak ifade ederken, 
Bonaiuto ve arkadaşları (1999) ise yerel bölgedeki sosyal ilişkilerin yere bağlılığı doğrudan etkilediğini ortaya koymuşlardır. Yerel bağların sosyal ilişkileri etkilediğini ortaya koyan bir diğer çalışma ise Mesch ve Manor (1998) tarafından yapılmışıı. Söz konusu araştırmacılar yakın çevrede yaşayan yakın arkadaşların sayısı arttıkça, mahalleye olan bağlılıklarının da arttığını ortaya koymuşlardır (Mesch ve Manor, 1998 akt. Rollero ve Piccoli 2010). Bazı araştırmalar ise yere bağlılığı çevreye yönelik duygusal bağ ile ilişkilendirmişlerdir ve yere bağlı olan insanların yerel katılım ve sosyal eylemler ile ilişkili olduğunu ortaya koymuşlardır. Örneğin Lewisca (2005)'nın yaptığı çalışma mahallelerine yüksek bağlılık gösteren ve köklerine aidiyet hisseden katılımcıların kar amacı gütmeyen sivil toplum kuruluşlarına ve sivil faaliyetlere katılım oranının yüksek olduğunu ortaya koymaktadır. Başka bir ifadeyle, kökenlerini keşfeden insanlar yaşadıkları coğrafya ile ilgili olaylara ve olgulara kayıtsız kalmamakta ve sivil sorumluluklar üstlenmektedirler.

\section{Turizm Alanyazınında Yere Bağlılık Kavramının Yeri ve Önemi}

Son 20 yılda yapılan araştırmalar, yerel sakinlerin turizm yönetimi ve gelişimine yönelik tutumunu ve algısını değerlendirmede yere bağlilığın faydasına ilişkin deneysel kanıtlar sağlamıştır (Gu ve Ryan 2008; Wang ve Chen 2015; Stylidis 2017; Guo vd, 2018; Dwyer vd, 2019). Örneğin Mccool ve Martin (1994) yere bağlılığın yerel sakinler ile turizm endüstrisinin bir arada başarılı bir şekilde yaşamasının belirleyicileri arasında olabileceğini ifade etmiştir. Ayrıca söz konusu yazarlar yerel sakinlerin duyguları ve tutumları üzerine yapılan araştırmaların bir destinasyondaki olumlu etkileri en üst düzeye çıkaran ve ev sahibi topluluk üzerindeki olumsuz etkileri en aza indiren kalkınma türlerini seçme konusunda yardımcı olacağını düşündüklerini de belirtmişlerdir. Wang ve Chen (2015) yerel sakinlerin turizme yönelik tutumlarının yer kimliği ve turizm desteği niyetleri arasındaki ilişkiye aracılık ettiğini, yer temelli benlik saygısı, öz yeterlik, süreklilik ve ayırt etme duyusunu içeren değişkenlerin ise yerel halkın turizme yönelik alg1 ve tutumlarında etkili olduğunu belirlemişlerdir. Bu bağlamda Wang ve Chen (2015) yerel sakinlerin topluluğun kendine özgü imajını pozitif algılamasının kendine olan sosyal saygısını arttırırken, olumsuz algılamasının ise öz saygı duygusunu azaltabileceğini ortaya koymaktadır. Bununla birlikte Wang ve Chen (2015) bölgedeki ikamet süresinin yer kimliği ve turizme karşı tutum arasındaki ilişkinin şiddetini de belirlediğini göstermişlerdir.

Eusébio ve arkadaşlarının (2018) Boa Vista Adası'nda (Cape Verde) yaptıkları çalışmaları ise, yerel sakinlerin yere bağlılığının yalnızca turizmin algılanan etkisini değil, aynı zamanda turizme yönelik tutumunu da olumlu yönde etkilediğini ortaya koymuştur. Benzer bir şekilde, Gu ve Ryan (2008)'in Shi Cha Hai Hutong'da (Pekin) yaptıkları çalışmada yerel sakinlerin yere bağllıklarının turizme dair tutumlarını olumlu yönde etkilediğini göstermiştir (Eusébio vd, 2018 ve Gu ve Ryan 2008'den akt. Shen vd, 2019). Shen ve arkadaşları (2019) turizme karş1 olumlu bir tavır sergileyen yerel sakinlerin daha yüksek turizm yanlısı davranışsal niyetlere sahip olduklarını bulmuştur. Ayrıca Shen ve arkadaşları (2019) yere bağlılık ile turizme karşı tutum arasında pozitif bir ilişki olduğunu ve yerel sakinlerin yere bağlılı̆̆ ne kadar yüksekse, turizme karşı tutumlarının da o kadar olumlu olduğunu tespit etmişlerdir. Gürsoy ve Rutherford (2004)'da yerel sakinlerin yere bağll1kkları arttıkça turizmin ekonomik ve sosyal etkilerini yere daha az bağlı olan sakinlere göre daha olumlu bir şekilde algıladıklarını bildirmişlerdir. Haralambopoulos ve Pizam (1996)'ın Yunanistan'ın Samos Adası'nda yaptıkları çalışma ve Snaith ve Haley (1999)'ın Birleşik Krallık'ın York şehrinde yaptıkları araştırma ise, bir yerde ikamet süresi ne kadar kısaysa, yerel sakinlerin turizmin etkilerine ilişkin algısının da o kadar olumlu olduğunu ortaya koymaktadır (Haralambopoulos ve Pizam 1996 ve Snaith ve Haley 1999'dan akt. Stylidis, 2017).

Chen ve Dwyer (2017), yer memnuniyeti ve yere bağlılığın yerel sakinlerin vatandaşlık davranışları üzerindeki etkilerini araştırdıkları çalışmalarında, yer beklentisinin (place expectation) bölge sakinlerinin bölgesel turizm gelişimine proaktif katılımını motive ettiğini bulmuştur (Chen ve Dwyer 2017). Song ve Soopramanien (2019), Çinli şehir sakinlerinin çevre yanlısı davranışlarını etkilemede sosyal bağın önemli bir rolü olduğunu ortaya koymuşlardır. Benzer bir şekilde Guo, Zhang, Zhang ve Zheng'in (2018) çalışma bulguları, turizm destinasyonlarında yaşayanların algılanan dayanıklılığı (perceived resilience) üzerinde yer kimliği ve yer bağımlılı̆̆ının olumlu etkilerini göstermiştir (Zhang ve Zheng'in 2018 akt. Dwyer vd, 2019). Mason ve Cheyne (2000) bölge sakinlerinin kimliklerinin turizm gelişmesi ile tehdit edildiğini hissediyorlarsa turizme karşı çıktıklarını belirlemişlerdir. Örneğin kaynak temelli endüstrilerde çalışan ve yüksek düzeyde mesleki kimliğe sahip olan sakinler, bir kalkınma stratejisi olarak turizme karşı çıkmaktadırlar. Buna karşılık, turizm gelişiminin yer kimlikleriyle tutarlı olduğunu düşünen yerel sakinlerin turizmden yana olma olasılı̆̆ı daha yüksek olmaktadır (Mason ve Cheyne 2000'den akt. Wang ve Chen 2015). 
Yere bağlılık ve turizm etkileri ile ilgili yapılan araştırmalar incelendiğinde yere bağlılık ve turizmin ilişkisini belirleyen değişkenleri belirlemek üzere yapılan çalışmaların bulguları arasında birbiriyle çelişen sonuçların olduğu görülmektedir. Örneğin Um ve Crompton (1987) yerel sakinler kendilerini ikamet süresi, doğum yeri ve etnik miras açısından bir topluluğa ne kadar bağlı hissediyorlarsa, toplumlarında turizmin gelişmesini o kadar az olumlu algıladıklarını ortaya koymuşlardır. Ayrıca bölge sakinlerinin turizmin çevre kalitesi üzerindeki etkilerine ilişkin algılarının bağlanma düzeyleriyle önemli ölçüde ilişkili olmadığını gözlemlemişlerdir (Um ve Crompton, 1987'den akt. Wang ve Chen 2015). Ancak McCool ve Martin (1994), yere güçlü bir şekilde bağlanan yerel sakinlerin turizmin olumlu boyutunu yere karşı bağ hissetmeyen sakinlerden daha yüksek olarak algıladıklarını tespit etmişlerdir. Yere bağlılık ve turizmin etkilerinin algılanması arasındaki ilişkinin anlaşılmasına dair yapılan çalışmaların bulgularındaki bu gibi tutarsızlıkların ölçüm yöntemlerindeki farklılıklardan kaynaklandığı söylenebilir. Bu yazında bahsedilen araştırmaların kavramsal çerçevesinin test edilmesinde genellikle yapısal eşitlik modellemesi, regresyon ve korelasyon analizlerinden yararlanıldı̆̆ı görülmektedir.

\section{MATERYAL VE YÖNTEM}

\section{1. Örneklem Seçimi ve Yöntemi}

$\mathrm{Bu}$ çalışma farklı uygarlık ve dönemlere ait sivil, dini ve anıtsal mimari ögeleri, vista noktaları ve Geç Osmanlı Dönemi yerleşim dokularını içeren Amasya'nın Merkez ilçesindeki Dere, Fethiye, Hatuniye, Gökmedrese, Sofular, Nergis, Savadiye, Şamlar, Şehirüstü ve Üçler mahallelerinde yapılmıştır. Araştırmanın evrenini çalışmanın örneklem yapısını oluşturan on mahallenin 2017 yılı hane sayıları oluşturmaktadır (TÜİK 2017). Toplam örneklem sayısı, \%95 güven aralığı ve $\pm 0,05$ örnekleme hatası ile 3336 hane için 345 hane olarak belirlenmiştir. Toplam örneklem sayısı bulunduktan sonra her mahallede uygulanacak anket büyüklüğü toplam içinde temsil edilme oranları doğrultusunda belirlenmiştir. Her haneden sadece 18 yaş ve yukarısındaki bir bireye Kasım ve Aralık 2017 tarihleri arasında basit tesadüfi örnekleme yöntemi kullanılarak anket uygulanmıştır. Bu süreç içerisinde ankete toplam 460 hane cevap vermeyi kabul etmiştir. Ayrıca araştırmanın derinliğini arttırmak amacıyla Hatuniye Mahallesi ve Sofular Mahallesi muhtarları ve ileri gelenleri ile derinlemesine mülakat yapılmıştır. Derinlemesine mülakat için bu iki mahallenin seçilmesinin nedenleri şu şekilde özetlenebilir: (1) Hatuniye mahallesi 1990 yılından günümüze izlenen turizm odaklı fonksiyon değişiklikleri nedeniyle ticari eksenli bir soylulaştırmaya maruz kalmıştır. (2) Sofular mahallesinin seçilmesindeki neden ise mahallenin turizme kazandırılmasının hedeflenmesidir. Bu amaçla mahallede 2011 yılında sokak sağlıklaştırılması yapılmış ve ayrıca mahallede yer alan iki adet tescilli bina İl Özel İdaresi tarafından satın alınarak restorasyonuna başlanmıştır (Amasya Valiliği, 2020).

\subsection{Hane Halkı Soru Formu İçeriği}

Anket formu dört bölümden oluşmaktadır. İlk bölümde, katılımcıların sosyo demografik özelliklerini belirlemeye yönelik olarak hazırlanan 15 adet soru yer almaktadır. İkinci bölüm katılımcıların yere bağlılığını ölçmek üzere hazırlanan 16 adet ifadeden oluşmaktadır (Hidalgo ve Hernandez 2001; Yoon 2002; Lewicka 2005; Göregenli 2010). Üçüncü bölümde turizm gelişimini destekleme düzeyini ölçmek amacıyla 4 adet soru bulunmaktadır. Dördüncü bölümde ise merkezi ve yerel yönetimlerin turizm gelişmesi için ortaya koyduğu kültürel mirasa yönelik stratejileri merkezine alan 11 adet ifadeden oluşan bir ölçeğe yer verilmiştir (Altanlar 2015). Anketin ikinci, üçüncü ve dördüncü bölümündeki ifadeler 5'li likert ölçeğine (1: Kesinlikle Katılmıyorum - 5: Kesinlikler Katılıyorum) göre sorgulanmaktadır.

\section{3. Ölçüm Yöntemi ve Teknikleri}

Çalışmada nominal ve ordinal ölçekteki değişsenlerin betimlenmesi için Frekans analizi yapılmıştır. Yere Bağlılık ve turizm stratejileri ölçeklerinin yapı geçerliğinin belirlenmesi amacıyla açımlayıcı faktör analizinden temel bileşenler analizi (Principal Component Analysis-TBA); döndürme yöntemi olarak da dik döndürme yöntemlerinden maksimum değişkenlik (varimax); güvenirliğinin belirlenmesi amacıyla Cronbach’s alfa güvenirlik testi uygulanmıştır. Ölçek puanlarının normalliğinin test edilmesinde çarpıklık ve basıklık katsayıları kullanılmış, katılımcıların yere bağlılık ölçeği ile turizm odaklı kararlar, turizm katılımı ve desteği ile ilgili verilen ifadeler arasındaki ilişkiyi ve şiddetini belirleyebilmek için, parametrik olmayan test tekniklerinden "Spearman Korelasyon" testi; hesaplanan yere bağlılık ve turizm stratejileri puanları arasındaki ilişkiyi ve şiddetini belirleyebilmek için parametrik test tekniklerinden "Pearson Korelasyon" testi; yere bağlılık ile turizmin algılanan etkilerini ortaya koyan üç veya daha fazla sayıda

Yere Bağlılı̆ın Turizm Stratejileri Üzerindeki Etkisi: Amasya Örneği

Journal of Urban Academy | Volume: 14 Issue: 1 | ISSN: 2146-9229

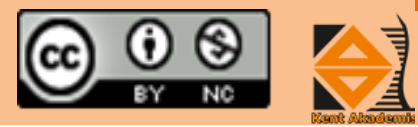


grubun ortalamaları arasındaki farkın anlamlılığını test etmek amacıyla Kruskal Wallis analizinden yararlanılmıştır. Ek olarak turizm stratejileri algısı üzerinde yere bağlılığın etkisi çoklu doğrusal regresyon analizi ile test edilmiştir (Şekil 1).

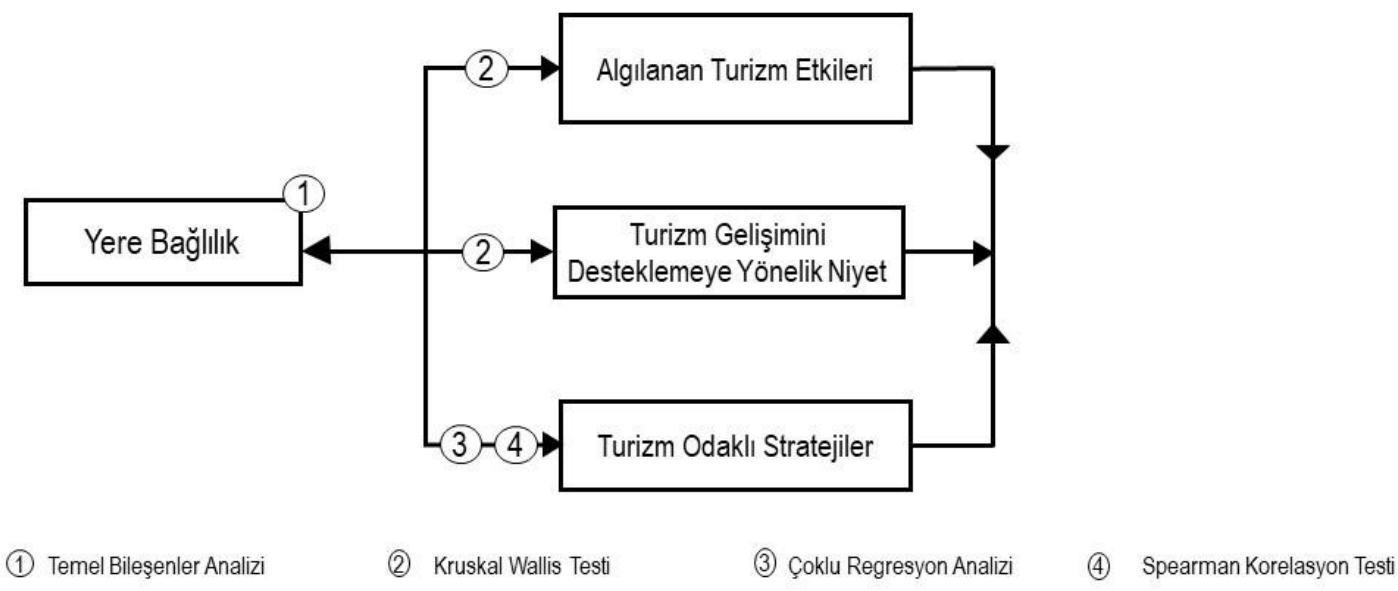

Şekil 1. Kavramsal Çerçeve ve Araştırma Yöntemi

\subsection{Araştırmanın Sınırlılıkları}

$\mathrm{Bu}$ araştırmanın kuramsal çerçevesi yalnızca ulaşılabilen literatür kaynaklarından derlenmiştir. Çalışmada yere bağlılık bir bireyin yerle kurduğu ilişkilerin duyuşsal bileşenleri de göz önüne alınarak insan ve yer ilişkilerinin her biçimini kapsayan bir üst kavram olarak ele alınmıştır. Bu yönüyle araştırmanın bir sınırlılığa sahip olduğu söylenebilir. Bununla birlikte, kentlerin göç alma hızı, gelişme potansiyelleri, geleneksel dokunun niteliği, turizm potansiyeli mahalle sakinlerinin ve yerel yönetimlerin yaklaşımları, her kentte tarihsel ve kültürel çevrenin korunmasını da odak alan turizm planı ve yönetimini farklı kılmaktadır. Bu nedenle çalışmanın bulgularının tarihi çevre ve tarihi mahalleler üzerinden yapılacak bir genellemeye imkan vermeyeceği de unutulmamalıdır.

\section{BULGULAR}

\subsection{Yere Bağlılık ve Turizm Stratejileri Ölçeklerini Belirleyen Faktörler}

Tablo 1'de yere bağlılık ölçeğinin maddelerinin faktör dağılımı ve güvenilirlik analizi sonuçları görülmektedir. Yere bağlılık ölçeğinin yapı geçerliğinin belirlenmesi amacıyla yapılan açımlayıcı faktör analizinin (Principal Component Analysis-TBA) screen plot grafiği incelendiğinde, faktör sayısının iki olmasına karar verilmiştir. Ayrıca bu karar, aracın geliştirilmesi sürecinde belirlenen teorik yapıda beklenen faktör sayısı ile uyumlu olması açısından da anlamlıdır. İki faktörün toplam varyans yüzdesi 44,587 olduğu için sosyal bilimlerde kabul edilebilir bir varyans oranıdır (Çokluk vd., 2012). Her iki faktörü oluşturan değişkenlerin faktör yükleri 0,400'den büyük ve her faktörün Cronbach alfa değer 0,7 'den büyüktür. İlk faktör komşuluk ilişkileri, mahalledeki sosyal aktivitelere katılım gibi bir yerdeki sosyal ortama duyulan bağlılı̆̆ içeren ifadelerden oluştuğu için "sosyal bağlılık" olarak kavramsallaştırılmıştır. İkinci faktör insanlar ve yerler arasında bilişsel, yargılar ve kararlar yoluyla oluşan duygusal ilişkiyi ortaya koyan ifadeleri içerdiği için “yere bağımlılık” olarak kavramsallaştırılmıştır. 
Tablo 1. Yere Bağlılık Ölçeğinin Faktör Dağılımı ve Güvenirlik Analizi Sonuçları

\begin{tabular}{|c|c|c|c|c|}
\hline & Madde & Faktör Yükü & $\begin{array}{c}\text { Açıklanan } \\
\text { Varyans } \\
\text { Oranı }\end{array}$ & $\begin{array}{l}\text { *Cronbach's Alpha } \\
\text { (Toplam: 0,867) }\end{array}$ \\
\hline \multirow{8}{*}{ 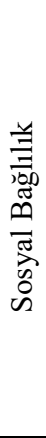 } & $\mathrm{Bu}$ mahalledeki insanlar birbirlerine bağlıdırlar. & 0,729 & \multirow{8}{*}{36,582} & \multirow{8}{*}{0,818} \\
\hline & $\begin{array}{l}\text { Bu mahallede yaşayan birçok kimse toplanıp el birliğiyle bir } \\
\text { mahallelinin isini görür. }\end{array}$ & 0,649 & & \\
\hline & $\begin{array}{l}\text { Bu mahalleyi eleştiren kişiler olduğunda mahallemi eleştirenlere } \\
\text { karș1 savunurum. }\end{array}$ & 0,605 & & \\
\hline & Bu mahalledeki insanlar aynı değerleri paylaşırlar, & 0,602 & & \\
\hline & Bu mahalleyi seviyorum. & 0,601 & & \\
\hline & Bu mahalledeki insanlar güvenilirdir. & 0,598 & & \\
\hline & $\begin{array}{l}\text { Bu mahalle ile ilgili herhangi bir konuda bir şey yapmak } \\
\text { istemem. }\end{array}$ & $-0,593$ & & \\
\hline & Bu mahallede insanlar genellikle birbirlerini tanırlar. & 0,519 & & \\
\hline \multirow{8}{*}{ 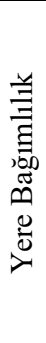 } & Bu mahalleye kök saldığımı hissediyorum. & 0,687 & \multirow{8}{*}{8,004} & \multirow{8}{*}{0,776} \\
\hline & Tüm hayatım bu mahallede geçmiştir. & 0,613 & & \\
\hline & Kendimi bu mahalleye ait hissediyorum. & 0,613 & & \\
\hline & Burada olmadığımda mahallemi özlüyorum. & 0,611 & & \\
\hline & Bu mahallede olup bitenleri bilmek isterim. & 0,602 & & \\
\hline & $\mathrm{Bu}$ mahalleden taşınmayı isterim. & $-0,582$ & & \\
\hline & Kendimi bu mahalleye yabancı hissediyorum. & $-0,535$ & & \\
\hline & Bu mahalle ile bağlarımın koptuğunu hissediyorum. & $-0,474$ & & \\
\hline
\end{tabular}

Tablo 2'de turizm stratejileri ölçeğinin maddelerinin faktör dağılımı ve güvenilirlik analizi sonuçları görülmektedir. Turizm stratejileri ölçeğinin yapı geçerliğinin belirlenmesi amacıyla da açımlayıcı faktör analizi (Principal Component Analysis-TBA) yapılmıştır. Yapılan faktör analizinin scree plot grafiği incelendiğinde, faktör sayısının iki olması gerektiği anlaşılmaktadır. İki faktörün toplam varyans yüzdesi yüzde 65,762 olarak tespit edilmiştir. Her iki faktörü oluşturan değişkenlerin faktör yükleri 0,400 'den büyük ve her faktörün Cronbach alfa değer 0,9 'dan büyüktür. İlk faktör, turizmin geliştirilmesi için merkezi ve yerel yönetimler tarafından yapılan program ve teşvikleri içeren ifadelerden oluştuğu için "turizm odaklı kararlar"; ikinci faktör yerel turistik girişim türleri ve eğilimleri ekseninde uygulanan stratejiler ve mahalle sakinlerinin desteği ve bu tür girişimlere katılma eğilimi ile ilgili ifadeleri içerdiği için "turizm desteği ve katılım" olarak kavramsallaştırılmıştır.

Yere Bağlılık, turizm stratejileri ölçeklerinin ölçek puanlarının normalliğinin test edilmesinde çarpıklık ve basıklık katsayıları incelenmiş̧tir. Puanların basıklık ve çarpıklık değerlerinin +3 ile -3 arasında olması normal dağılım için yeterli görülmektedir (Hopkins ve Weeks, 1990; De Carlo, 1997). Buna göre puanların çarpıklık (Sosyal Bağlllık=0,681, Yere Bağımlılık=-1,061, Turizm Odaklı Kararlar=-1,045, Turizm Desteği ve Katılım=-0,210) ve basıklık (Sosyal Bağlılık=0,729, Yere Bağımlılık=2,042, Turizm Odaklı Kararlar=0,456, Turizm Desteği ve Katılım=-1,344) istatistiklerinin sınırlar içerisinde olduğu, normal dağılım gösterdiği kabul edilmiştir. Puanlara ilişkin analizlerde parametrik yöntemler kullanılmıştır. Likert düzeyde olan sorular ve ölçek ifadeleri ile ilişkiyi ortaya koyan analizlerde ise parametrik olmayan yöntemler kullanılmıştır. Bu değişkenler 1 ile 5 aralığında cevap alan kesikli değişkenlerdir. 
Tablo 2. Turizm Stratejileri Ölçeğinin Faktör Dağılımı ve Güvenirlik Analizi Sonuçları

\begin{tabular}{|c|c|c|c|c|}
\hline & Madde & $\begin{array}{c}\text { Faktör } \\
\text { Yükü }\end{array}$ & $\begin{array}{l}\text { Açıklanan } \\
\text { Varyans } \\
\text { Oranı }\end{array}$ & $\begin{array}{c}\text { *Cronbach's } \\
\text { Alpha } \\
\text { (Toplam=0,908) }\end{array}$ \\
\hline 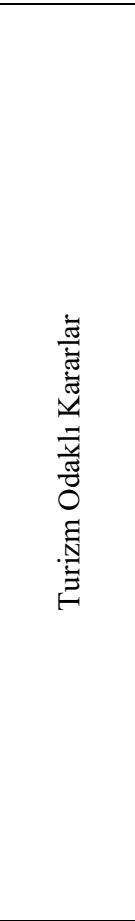 & $\begin{array}{l}\text { Merkezi ve yerel yönetimler mimari mirasın korunması ve yaşatılması } \\
\text { konusunda kapsamlı ve güncel kararlar almaktadır. } \\
\text { Merkezi ve yerel yönetimlerin tarihi yapıların restorasyonu (yenileme) } \\
\text { için verdiği teşvik ve krediler yeterli düzeydedir. } \\
\text { Merkezi ve yerel yönetimler mahallemizde turizmin geliştirilmesiyle } \\
\text { ilgili aldığı karar ve uygulamalardan bizleri haberdar ediyor. } \\
\text { Merkezi ve yerel yönetimler tarihi çevrede yapılacak yeni yapıların } \\
\text { çevreye aykırı olmalarını önleyici kararlar almakta ve yönetmelikler } \\
\text { düzenlemektedir. } \\
\text { Merkezi ve yerel yönetimler mevcut ve gelecekteki ihtiyaca cevap } \\
\text { verebilmek için mahallemizin altyapısını (su, kanalizasyon, doğal gaz, } \\
\text { elektrik, içme suyu gibi) iyileştiriyor. } \\
\text { Merkezi ve yerel yönetimler mahallemizdeki tarihi yapıların nasıl } \\
\text { korunması gerektiği hakkında danışmanlık hizmeti veriyor. } \\
\text { Merkezi ve yerel yönetimler mahallemizdeki tarihi yapıları } \\
\text { koruyabilmemiz için araştırma yaptırmak ve bilirkişi tavsiyesi } \\
\text { alabilmek için finansal kaynak sağlıyor. } \\
\text { Geleneksel kültürü canlandırmak için ücretsiz/ düşük ücretli eğitim } \\
\text { programları gerçekleştiriyor. } \\
\text { Kültür miraslarımız ile ilgili toplumsal bilinci arttırmak için eğitim ve } \\
\text { seminerler düzenlemektedir. } \\
\text { Merkezi ve yerel yönetimler turizm geliştirilmesi ilgili karar üretmede } \\
\text { sivil vatandaşların katılımını teşvik eder. } \\
\text { Merkezi ve yerel yönetimler geleneksel el sanatlarımızı, yemek } \\
\text { kültürümüzü yaşatmamı için eğitim ve seminerler düzenlemektedir. }\end{array}$ & 0,823 & 43,195 & 0,933 \\
\hline 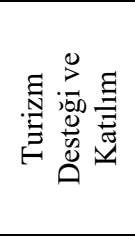 & $\begin{array}{l}\text { Turizm geliştirilirse, evimin bir bölümünü turistlere kiralarım. } \\
\text { Komşularımın evlerinin bir bölümünü turistlere kiralamasını } \\
\text { desteklerim. } \\
\text { Evimi otel, pansiyon, restoran gibi işletmelerin açılması için kiralarım. } \\
\text { Komşularımın evlerini otel, pansiyon, restoran gibi işletmelere } \\
\text { kiralamasını desteklerim. }\end{array}$ & 0,916 & 22,567 & 0,930 \\
\hline
\end{tabular}

\subsection{Yerel Sakinlerin Yere Bağlılığı ve Turizm Gelişimine Yönelik Algısı ve Desteği}

Katılımcıların turizm gelişimine karşı genel tutumlarını ölçmek amacıyla sorulan "Amasya'da turizmin gelişmesini ister misiniz?" sorusuna verdikleri yanıtlar ile yere bağlılık ölçeği anlamlı bir farklılık olup olmadığını ortaya koymak üzere yapılan Kruskal Wallis testi analiz sonuçları Tablo 2'de verilmiştir. Elde edilen bulgular, Amasya'da turizmin gelişmesini isteme düzeyi ile "sosyal bağlılık" ve "yere bağımlılık" boyutu arasında istatistiksel olarak anlamlı bir farklılık olduğunu göstermektedir. Amasya'da turizmin gelişmesini "kesinlikle isterim" şeklinde yanıtlayan katılımcıların "sosyal bağlılık" (X: 296,45) ve "yere bağımlılık" (X: 269,01) boyutlarının her ikisinin de en yüksek puanı aldığı belirlenmektedir. Benzer bir şekilde mahallede turizm gelişmesini isteme düzeyi ile "sosyal bağllık" ve "yere bağımlılık" boyutları arasında da istatistiksel olarak anlamlı bir farklılık olduğu tespit edilmiştir. Mahallesinde turizmin gelişmesini istemeyenlerin "sosyal bağl1lık" boyutu puanının en düşük ( $\overline{\mathrm{X}}$ : 151,87) olduğu belirlenirken, kesinlikle isteyenlerin "sosyal bağl1lı" boyutu puanlarının en yüksek (X: 307,82) olduğu; mahallesinde turizmin gelişmesini istemeyenlerin "yere bağımlılık" boyutu puanı en düşük iken ( $\overline{\mathrm{X}}: 144,15)$, kesinlikle isteyenlerin en yüksek (X̄: 272,57) olduğu görülmektedir (Tablo 3). 
Yapılan analize göre katılımcıların mahalledeki turizm faaliyetlerinin etkilerine dair genel algısı ile yere bağl1lık ölçeği arasında anlamlı bir farklılık olduğu belirlenmiştir. Mahallesinde turizmin gelişmesini "ne olumlu ne olumsuz" bulan katılımcıların "sosyal bağlllık" boyutu puanı en düşük iken (X:169,75), "çok olumlu" bulan katılımcıların "sosyal bağlılık" boyutu puanının en yüksek (X̄:306,75) olduğu anlaşılmaktadır. Benzer bir şekilde, katılımcıların mahallelerindeki turizm faaliyetlerine dair genel algıları ile "yere bağımlılık" boyutu arasında da istatistiksel olarak anlamlı bir farklılık bulunmuştur. Elde edilen bulgular mahallesindeki turizm gelişmesini "ne olumlu nede olumsuz" olarak nitelendiren katılımcıların "yere bağımlılık" boyutu puan ortalamasının en düşük (X:172,87) olduğunu gösterirken, çok olumlu olarak nitelendiren katılımcıların "yere bağımlılık" boyutu puan ortalamasının en yüksek olduğunu (X):303,21) ortaya koymaktadır (Tablo 3).

Tablo 3. Turizm Yanlısı Davranışsal Niyet, Turizm Desteği ve Turizm Etkilerinin Yere Bağlılık Ölçek Puanları Bakımından Kruskal Wallis Testi ile Karşılaştırılması

\begin{tabular}{|c|c|c|c|c|c|}
\hline & & $\mathrm{n}$ & Sira Ortalama & $X^{2}$ & $\mathrm{p}$ \\
\hline \multicolumn{2}{|c|}{ Amasya' da turizm gelişmesini ister misiniz? } & 460 & 4,3826 & & \\
\hline \multirow{3}{*}{ Sosyal Bağlılık } & İstemem ya da kararsız kalırım & 12 & 124,08 & \multirow{3}{*}{87,014} & \multirow{3}{*}{$0,000^{*}$} \\
\hline & İsterim & 252 & 184,27 & & \\
\hline & Kesinlikle isterim & 196 & 296,45 & & \\
\hline \multirow{3}{*}{ Yere Bağımlılık } & İstemem ya da kararsız kalırım & 12 & 119,63 & \multirow{3}{*}{33,718} & \multirow{3}{*}{$0,000 *$} \\
\hline & İsterim & 252 & 205,83 & & \\
\hline & Kesinlikle isterim & 196 & 269,01 & & \\
\hline Mahallenizde tur & esini ister misiniz? & 460 & 4,0935 & & \\
\hline \multirow{5}{*}{ Sosyal Bağlılık } & Kesinlikle istemem & 17 & 264,91 & \multirow{5}{*}{90,189} & \multirow{5}{*}{$0,000 *$} \\
\hline & İstemem & 23 & 151,87 & & \\
\hline & Kararsızım & 19 & 186,34 & & \\
\hline & İsterim & 242 & 188,22 & & \\
\hline & Kesinlikle isterim & 159 & 307,82 & & \\
\hline \multirow{5}{*}{ Yere Bağımlılık } & Kesinlikle istemem & 17 & 246,41 & \multirow{5}{*}{31,615} & \multirow{5}{*}{$0,000 *$} \\
\hline & İstemem & 23 & 144,15 & & \\
\hline & Kararsızım & 19 & 222,58 & & \\
\hline & İsterim & 242 & 210,57 & & \\
\hline & Kesinlikle isterim & 159 & 272,57 & & \\
\hline $\begin{array}{l}\text { Mahallenizdeki t } \\
\text { algiliyorsunuz? }\end{array}$ & iminin genel etkilerini nasıl & 460 & 3,3239 & & \\
\hline \multirow{5}{*}{ Sosyal Bağlılık } & Çok olumsuz & 36 & 277.13 & \multirow{5}{*}{38.082} & \multirow{5}{*}{$0,000 *$} \\
\hline & Olumsuz & 98 & 212,63 & & \\
\hline & Ne olumlu ne de olumsuz & 63 & 169,75 & & \\
\hline & Olumlu & 207 & 228,71 & & \\
\hline & Çok olumlu & 56 & 306,75 & & \\
\hline \multirow{5}{*}{ Yere Bağımlılık } & Çok olumsuz & 36 & 184,78 & \multirow{5}{*}{41,976} & \multirow{5}{*}{$0,000^{*}$} \\
\hline & Olumsuz & 98 & 266,79 & & \\
\hline & Ne olumlu ne de olumsuz & 63 & 172,87 & & \\
\hline & Olumlu & 207 & 219,14 & & \\
\hline & Çok olumlu & 56 & 303,21 & & \\
\hline
\end{tabular}




\subsection{Yere Bağlılık ve Turizm Stratejileri Arasındaki Etkileşim}

Yere bağllık ile turizm stratejileri arasındaki etkiyi ortaya koyabilmek için çoklu regresyon analizi ve korelasyon analizleri yapılmıştır. Bulgular yere bağımlılık boyutunun $(\beta=0,196 ; \mathrm{p}<0,05)$ turizm odaklı kararlar üzerinde pozitif ve istatistiki olarak anlamlı bir etkiye sahip olduğunu ancak sosyal bağlılığın $(\beta=0,054 ; p>0,05)$ ise etkili olmadığını ortaya koymaktadır. Turizm desteği ve katılımı boyutu üzerinde ise hem sosyal bağllık $(\beta=-0,029 ; \mathrm{p}>0,05)$ hemde yere bağımlılık boyutlarının $(\beta=0,109 ; \mathrm{p}>0,05)$ istatistiksel olarak anlamlı bir etkisinin olmadığı göstermektedir (Tablo $4)$.

Tablo 4. Yere Bağlılığın Turizm Odaklı Kararlar, Turizm Desteği ve Katılım Boyutlarına Etkisi

\begin{tabular}{llcccccc}
\hline & & \multicolumn{3}{c}{ Katsayılar } & \multicolumn{3}{c}{ Model } \\
\cline { 2 - 8 } & Boyut & $\boldsymbol{\beta}$ & $\mathbf{t}$ & $\mathbf{p}$ & \multirow{2}{*}{$\mathbf{R}^{2}$} & F & $\begin{array}{c}\text { Durbin } \\
\text { Watson }\end{array}$ \\
\hline Turizm Odaklı & Sosyal Bağlılık & 0,054 & 0,917 & $\mathbf{0 , 3 6 0}$ & \multirow{2}{*}{0,055} & \multirow{2}{*}{$13,185^{*}$} & \multirow{2}{*}{1,099} \\
Kararlar & Yere Bağımlılık & 0,196 & 3,334 & $\mathbf{0 , 0 0 1 *}$ & & \\
\hline Turizm Desteği ve & Sosyal Bağlılık & $-0,029$ & $-0,489$ & $\mathbf{0 , 6 2 5}$ & \multirow{2}{*}{0,009} & \multirow{2}{*}{2,017} & \multirow{2}{*}{1,155} \\
Katılım & Yere Bağımlılık & 0,109 & 1,818 & $\mathbf{0 , 0 7 0}$ & & & \\
\hline *p $<0,05$ anlamlı fark var, p $>0,05$ anlamlı fark yok & & & & & & \\
\hline
\end{tabular}

Yere bağl1lık ile turizm stratejilerini oluşturan boyutlar arasındaki ilişkinin nasıl olduğunu ortaya koyabilmek için ise sperman korelasyon testi yapılmıştır (Tablo 5; Tablo 6). Elde edilen bulgulara göre turizm katılımı ve desteği boyutunu oluşturan değişkenlerden sadece "turizm geliş̧irilirse, evimin bir bölümünü turistlere kiralarım" ifadesine katılım düzeyi ile "yere bağımlılık" boyutu arasında pozitif yönde zayıf şiddetli bir ilişki bulunduğu tespit edilmiştir (Tablo 5).

Tablo 5. Turizm Desteği ve Katılım Boyutu İfadeleri ve Puanları ile Yere Bağlılık Ölçek Puanları İlişsisi

\begin{tabular}{|c|c|c|c|c|c|}
\hline & & $\begin{array}{c}\text { Sosyal Bağlılık } \\
(\text { Ort=4,25 } \\
\text { ss=0,53) }\end{array}$ & $\begin{array}{c}\text { Yere Bağımlılık } \\
(\text { Ort=4,07 } \\
\text { ss=0,59) }\end{array}$ & Ort. & SS \\
\hline \multirow{2}{*}{ Turizm Desteği ve Katılım } & $\mathrm{r}$ & 0,040 & 0,091 & \multirow{2}{*}{3,01} & \multirow{2}{*}{1,33} \\
\hline & $\mathrm{p}$ & 0,395 & 0,052 & & \\
\hline \multirow{2}{*}{$\begin{array}{l}\text { Turizm geliştirilirse, evimin bir bölümünü } \\
\text { turistlere kiralarım. }\end{array}$} & $\mathrm{r}$ & 0,048 & $0,098^{*}$ & \multirow{2}{*}{2,89} & \multirow{2}{*}{1,51} \\
\hline & $\mathrm{p}$ & 0,303 & 0,036 & & \\
\hline \multirow{2}{*}{$\begin{array}{l}\text { Komşularımın evlerinin bir bölümünü turistlere } \\
\text { kiralamasını desteklerim. }\end{array}$} & $\mathrm{r}$ & $-0,003$ & 0,069 & \multirow{2}{*}{3,05} & \multirow{2}{*}{1,42} \\
\hline & $\mathrm{p}$ & 0,951 & 0,139 & & \\
\hline \multirow{2}{*}{$\begin{array}{l}\text { Evimi otel, pansiyon, restoran gibi işletmelerin } \\
\text { açılması için kiralarım. }\end{array}$} & $\mathrm{r}$ & 0,077 & 0,076 & \multirow{2}{*}{2,96} & \multirow{2}{*}{1,48} \\
\hline & $\mathrm{p}$ & 0,098 & 0,106 & & \\
\hline \multirow{2}{*}{$\begin{array}{l}\text { Komşularımın evlerini otel, pansiyon, restoran } \\
\text { gibi işletmelere kiralamasını desteklerim. }\end{array}$} & $\mathrm{r}$ & 0,046 & 0,078 & \multirow{2}{*}{3,15} & \multirow{2}{*}{1,42} \\
\hline & $\mathrm{p}$ & 0,330 & 0,094 & & \\
\hline
\end{tabular}

Yere bağl1lık ile turizm odaklı kararlar boyutunu oluşturan ifadeler arasındaki ilişkinin şiddetini ve yönünü ortaya koyabilmek için yapılmış Sperman Korelasyon testinin sonuçlarına göre ise; merkezi ve yerel yönetimlerin tarihi yapıların korunması ve yaşatılması konusunda girişimlerde bulunması $(\overline{\mathbf{X}}: 3,73)$, tarihi yapıların restorasyonu için yeterli düzeyde teşvik ve krediler sağlaması $(\overline{\mathbf{X}}: 3,76)$, mahalle sakinlerinin turizm gelişmesiyle ilgili karar alma 
sürecine dahil edilmesi ve alınan kararlardan haberdar edilmesi $(\overline{\mathbf{X}}: 3,62)$, yeni yapılaşmanın söz konusu olduğu durumlarda geleneksel kent dokularına uyumlu yapılaşma kararları için yönetmelikler düzenlemesi ve uygulatması $(\overline{\mathbf{X}}$ :3,77), mahalle sakinlerine tarihi çevre bilincini sağlamak ve geleneksel halk kültürünü devam ettirebilmek için el sanatları vb. konularda eğitim programları düzenlemesi $(\overline{\mathbf{X}}: 3,64)$, merkezi ve yerel yönetimler mevcut ve gelecekteki ihtiyaca cevap verebilmek için mahallemizin altyapısını iyileştiriyor $(\overline{\mathrm{X}}: 4,02)$ " merkezi ve yerel yönetimlerin mahalledeki tarihi yapıların korunması ile ilgili danışmanlık hizmeti vermesi ( $\bar{X}: 3,51)$, mahalledeki tarihi yapıların korunması için araştırma yapılması ve uzman desteği alınabilmesi için finansal kaynak sağlaması $(\overline{\mathrm{X}}: 3,47)$ ve kültürel miras ile ilgili toplumsal bilinci arttırmak amacıyla eğitim ve seminerler düzenlemesi ( $\overline{\mathrm{X}}: 3,64)$ gibi turizm ve koruma odaklı stratejilere mahalle sakinlerinin katılım düzeyi ile "sosyal bağlılık" ve "yere bağımlılık" boyutları arasında pozitif yönde zayıf şiddetli bir ilişki bulunduğu tespit edilmiştir. $\mathrm{Bu}$ durum mahalle sakinlerinin turizm odaklı stratejilere yönelik memnuniyetleri arttıkça yere bağlılıklarının da artacağını ortaya koymaktadır (ya da tam tersi). Benzer bir şekilde yerel yönetimlerin kültürel miras kaynaklarının korunması amacıyla yapacağı danışmanlık hizmetleri ve sağlayacağı finansal desteğin mahalle sakinlerinin yere bağlılıkları üzerinde olumlu bir etkisi olacağını da göstermektedir (Tablo 6).

Tablo 6. Mahalle Sakinlerinin Turizm Odaklı Stratejilere Dair Bakış Açısının Yere Bağlılık Ölçeği Arasındaki İlişki

\begin{tabular}{|c|c|c|c|c|c|}
\hline & & $\begin{array}{c}\text { Sosyal } \\
\text { Bağlılık } \\
(\text { Ort=4,25 } \\
\text { ss }=0,53)\end{array}$ & $\begin{array}{c}\text { Yere } \\
\text { Bağımlılık } \\
(\text { Ort=4,07 } \\
\text { SS }=\mathbf{0 , 5 9 )}\end{array}$ & Ort. & ss \\
\hline \multirow{2}{*}{ Turizm Odaklı Kararlar } & $\mathrm{r}$ &, $178^{* *}$ &, $230^{* *}$ & \multirow{2}{*}{3,69} & \multirow{2}{*}{0,88} \\
\hline & $\mathrm{p}$ & 0,000 & 0,000 & & \\
\hline \multirow{2}{*}{$\begin{array}{l}\text { Merkezi ve yerel yönetimler mimari mirasın korunması ve } \\
\text { yaşatılması konusunda kapsamlı ve güncel kararlar almaktadır. }\end{array}$} & $\mathrm{r}$ &, $289^{* *}$ &, $303^{* *}$ & \multirow{2}{*}{3,73} & \multirow{2}{*}{1,20} \\
\hline & $\mathrm{p}$ & 0,000 & 0,000 & & \\
\hline \multirow{2}{*}{$\begin{array}{l}\text { Merkezi ve yerel yönetimlerin tarihi yapıların restorasyonu } \\
\text { (yenileme) için verdiği teşvik ve krediler yeterli düzeydedir. }\end{array}$} & $\mathrm{r}$ &, $237^{* *}$ &, $255^{* *}$ & \multirow{2}{*}{3,76} & \multirow{2}{*}{1,14} \\
\hline & $\mathrm{p}$ & 0,000 & 0,000 & & \\
\hline \multirow{2}{*}{$\begin{array}{l}\text { Merkezi ve yerel yönetimler mahallemizde turizmin } \\
\text { geliştirilmesiyle ilgili aldığı karar ve uygulamalardan bizleri } \\
\text { haberdar ediyor. }\end{array}$} & $\mathrm{r}$ &, $198^{* *}$ &, $273^{* *}$ & \multirow[b]{2}{*}{3,62} & \multirow[b]{2}{*}{1,24} \\
\hline & $\mathrm{p}$ & 0,000 & 0,000 & & \\
\hline \multirow{2}{*}{$\begin{array}{l}\text { Merkezi ve yerel yönetimler tarihi çevrede yapılacak yeni } \\
\text { yapıların çevreye aykırı olmalarını önleyici kararlar almakta ve } \\
\text { yönetmelikler düzenlemektedir. }\end{array}$} & $\mathrm{r}$ &, $179^{* *}$ &, $201^{* *}$ & \multirow[b]{2}{*}{3,77} & \multirow[b]{2}{*}{1,09} \\
\hline & $\mathrm{p}$ & 0,000 & 0,000 & & \\
\hline \multirow{2}{*}{$\begin{array}{l}\text { Merkezi ve yerel yönetimler mevcut ve gelecekteki ihtiyaca } \\
\text { cevap verebilmek için mahallemizin altyapısını iyileştiriyor. }\end{array}$} & $\mathrm{r}$ & $277^{* *}$ & $175^{* *}$ & \multirow{2}{*}{4,02} & \multirow{2}{*}{0,97} \\
\hline & $\mathrm{p}$ & 0,000 & 0,000 & & \\
\hline \multirow{2}{*}{$\begin{array}{l}\text { Merkezi ve yerel yönetimler mahallemizdeki tarihi yapıların } \\
\text { nasıl korunması gerektiği hakkında danışmanlık hizmeti } \\
\text { veriyor. }\end{array}$} & $\mathrm{r}$ &, $102^{*}$ &, $222^{* *}$ & \multirow[b]{2}{*}{3,51} & \multirow[b]{2}{*}{1,22} \\
\hline & $\mathrm{p}$ & 0,029 & 0,000 & & \\
\hline \multirow{2}{*}{$\begin{array}{l}\text { Merkezi ve yerel yönetimler mahallemizdeki tarihi yapıları } \\
\text { koruyabilmemiz için araştırma yaptırmak ve bilirkişi tavsiyesi } \\
\text { alabilmek için finansal kaynak sağlıyor }\end{array}$} & $\mathrm{r}$ &, $107^{*}$ &, $226^{* *}$ & \multirow[b]{2}{*}{3,47} & \multirow[b]{2}{*}{1,21} \\
\hline & $\mathrm{p}$ & 0,021 & 0,000 & & \\
\hline \multirow{2}{*}{$\begin{array}{l}\text { Geleneksel kültürü canlandırmak için ücretsiz/ düşük ücretli } \\
\text { eğitim programları gerçekleştiriyor. }\end{array}$} & $\mathrm{r}$ & $225^{* *}$ & $248^{* *}$ & \multirow{2}{*}{3,60} & \multirow{2}{*}{1,15} \\
\hline & $\mathrm{p}$ & 0,000 & 0,000 & & \\
\hline \multirow{2}{*}{$\begin{array}{l}\text { Kültür miraslarımız ile ilgili toplumsal bilinci arttırmak için } \\
\text { eğitim ve seminerler düzenlemektedir. }\end{array}$} & $\mathrm{r}$ &, $189^{* *}$ & $266^{* *}$ & \multirow{2}{*}{3,64} & \multirow{2}{*}{1,20} \\
\hline & $\mathrm{p}$ & 0,000 & 0,000 & & \\
\hline \multirow{2}{*}{$\begin{array}{l}\text { Merkezi ve yerel yönetimler turizm geliştirilmesi ilgili karar } \\
\text { üretmede sivil vatandaşların katılımını teşvik eder. }\end{array}$} & $\mathrm{r}$ & $186^{* *}$ & $243^{* *}$ & \multirow{2}{*}{3,63} & \multirow{2}{*}{1,13} \\
\hline & $\mathrm{p}$ & 0,000 & 0,000 & & \\
\hline \multirow{2}{*}{$\begin{array}{l}\text { Merkezi ve yerel yönetimler geleneksel el sanatlarımızı, yemek } \\
\text { kültürümüzü yaşatmamız için eğitim ve seminerler } \\
\text { düzenlemektedir. }\end{array}$} & $\mathrm{r}$ & $210^{* *}$ & $208^{* *}$ & & \\
\hline & $\mathrm{p}$ & 0,000 & 0,000 & 3,79 & 1,09 \\
\hline
\end{tabular}


Anketin uygulanması sırasında Sofular ve Hatuniye mahallelerinde yapılan derinlemesine görüşmelerde mahalle sakinlerinin büyük bir çoğunluğunun tarihi yapıların bakım ve onarımlarının yapılması konusunda hangi tür hizmetlerden nasıl faydalanabileceği ve bu yapıların onarılması için merkezi ve yerel yönetimlerin ne tür destekler verebileceği konusunda bilgi sahibi olmadıkları tespit edilmiştir. Bilgi sahibi olan katılımcılar ise verilen maddi desteğin yeterli olmadığı ve onarım çalışmaları için plan, proje ve uygulama açısından teknik destek sağlayabilecekleri koruma alanında uzmanlaşmış kişi, kurum ve kuruluşlara ulaşabilmenin ise güç olduğunu ifade etmişlerdir. Ek olarak Sofular Mahallesindeki mülk sahiplerinden bazıları söz konusu tarihi yapıların bakım ve onarım maliyetlerinin yüksek olması nedeniyle ihtiyaç ve beklentilerine cevap verebilecek yeni konut alanlarına taşınmayı düşündüklerini ifade etmişlerdir. Bu durum gerekli müdahaleler yapılmazsa Sofular mahallesinin de Hatuniye Mahallesi’nde olduğu gibi turizme yönelik ticari bir soylulaştırmaya maruz kalarak özgün değerlerini yitirme tehlikesi ile karşı karşıya kalacağını ortaya koymaktadır.

\section{SONUÇ VE ÖNERILER}

Yere bağlılık ve tutum sırasıyla çevresel psikoloji ve sosyal psikolojide geliştirilen anahtar yapılardır. Dahası, çevre psikoloji alanı yere bağlılığın mahalle sakinlerinin turizme karşı davranış ve tutumları üzerindeki önemli etkisini uzun süredir kabul etmektedir. Bu çalışmada yapılan incelemenin çevre psikolojisi, şehir planlama ve turizm literatürünün genişletilmesine ve kavramsal olarak ilişkilendirilmesine katkıda bulunacağı düşünülmektedir. Bu nedenle çalışmada disiplinler arası bir anlayış ile yere bağlılık ve sürdürülebilir turizm konusu ele alınmıştır.

Çalışmada alanyazınındaki diğer çalışmalarda (Gu ve Ryan 2008; Gürsoy ve Rutherford 2004) olduğu gibi yere bağlılığın turizm gelişimi desteklemeye yönelik algıyı etkilediği üzerine bulgular elde edilmiştir. Elde edilen bulgular mahalle sakinlerinin sosyal bağımlılığı ve yere bağımlılığı ne kadar yüksekse, turizm gelişimine karşı tutumlarının da o kadar olumlu olduğunu göstermektedir. Benzer bir şekilde elde edilen bulgular, yere bağımlılıkları ve sosyal bağlılıkları yüksek olan mahalle sakinlerinin turizm gelişiminden yana olma olasılığının daha yüksek olduğunu ortaya koymaktadır. Ayrıca elde edilen bulgular McCool ve Martin (1994)'deki gibi mahalle sakinlerinin turizmin olumlu etkilerini yere karşı bağ hissetmeyen sakinlerden daha yüksek şekilde algılandıklarını ortaya koymaktadır. Ancak araştırma bulguları mahalle sakinlerinin turizm gelişiminden yana olmalarına rağmen sosyal bağları ve yere bağımlılığı yüksek olan sakinlerin mahallede küçük ölçekli turistik alışverişe olanak veren işletmelerin açılması ve düzenlenecek olan kültürel ve geleneksel etkinlere katkıda bulunma gibi girişimler konusunda kendilerini henüz hazır hissetmediklerini göstermektedir. Turizm planlaması yapılırken bu olguların arkasında yatan nedenlerin derinlemesine araştırılması ve bu gibi durumların nedenleri çözümlenerek mahalle sakinlerinin turizm faaliyetlerine katılımının sağlanması için alternatif öneriler geliştirilmesi gerekmektedir. $\mathrm{Bu}$ da ancak planlama aşamasında mahalle sakinleri ile diyalog kurma ve birlikte çalışma yoluyla sağlanabilir.

$\mathrm{Bu}$ çalışmanın bulguları mahalle sakinlerinin yere bağlılıkları ile turizm odaklı stratejileri algılamaları arasındaki ilişkiyi de ortaya koyarak diğer çalışmalardan farklılaşmaktadır. Elde edilen bulgular yere bağlılık ile turizm odaklı stratejilerin algılanan etkileri arasında pozitif bir ilişki olduğunu ortaya koymaktadır. Mahalle sakinlerinin turizm sosyal bağlılıkları ve yere bağımlılıkları arttıkça turizm odaklı stratejilere yönelik memnuniyetleri de artmaktadır (ya da tam tersi). Ayrıca elde edilen bulgular, sürdürülebilir turizm gelişimi amacıyla yapılan planlama sürecinin karar alma aşamalarında merkezi ve yerel yönetimlerin temsilcileri, kültürel kurum ve kuruluşlar ile yerel işletmeler ve mahalle sakinleri arasında bilgi alışverişi, danışmanlık ve iş birliğinin geliştirilmesinin önemini ortaya koymaktadır. Çalışmanın bulguları mahalle sakinlerinin tarihi yapıların korunması ve korumanın yaygınlaştırılması konusunda teknik ve finansal desteğe ihtiyaç duyduklarını ortaya koymaktadır. Bu bağlamda tarihi çevrenin iyileştirilmesi için gerekli kaynakların öncelikle kamu tarafından sağlanması ve özellikle yoksul kesimlere teknik ve maddi destek verilmesi gerektiği açıkça ortadır. Yörede yaşayan sakinleri tarihi çevre konusunda bilgilendirmek ve bilinçlendirmek, onların turizm konusunda olumlu katkı ve katılımlarının sağlanması açısından en önemli uygulama araçlarından biridir. Bu nedenle sürdürülebilir turizm gelişimine yönelik plan ve projeler yapılırken mahalle sakinlerinin eğitim, katılım, eşgüdüm konularında bilinçlendirilmesi konusuna ağırlık verilmesi gerekmektedir. Bu şekilde mahalle sakinlerinin konuya çok yönlü sahip çıkarak gönüllü denetçi rolünü üstlenmesi sağlanabilir.

Sonuç olarak elde edilen bulgular turizm odaklı gelişim için kapsamlı ve bütünleşik bir yaklaşıma ihtiyaç duyulduğunu ortaya koymaktadır. Turizm fonksiyonu bölgeye ekonomik bir getiri sağlayarak, bölgenin içsel, sosyal, Yere Bağlılı̆ın Turizm Stratejileri Üzerindeki Etkisi: Amasya Örneği 
ekonomik ve yapısal unsurlarının kuvvetlenmesini ve bölgenin kalkınmasını sağlayabilir. Ancak bunun gerçekleşmesi için turizm açısından çekim noktası olan tarihi kent merkezi ve mahallelerin geleneksel kimliği ve sahip olduğu potansiyelleri güçlendiren, bölgenin ölçeği ve genel kimliği ile çelişmeyecek bir yapılanma içinde kurgulanacak bir turizm senaryosuna ihtiyaç duyulmaktadır. Turizm odaklı müdahalelerde öncelikli hedef mahallenin kimliğini vurgulayıp öne çıkaracak sosyal ve mekânsal stratejiler olmalıdır. Bu amaçla mahalledeki konut kullanımını zedelemeyen, tarihi konutları tahrip etmeyen, konutlarda yaşamlarını sürdürmekte olan mülk sahibi kullanıcıların ve kiracıların alandan çekilmesini tetiklemeyen bir turizm anlayışı hedeflenmelidir (Turgut ve Özden 2005). Özetlemek gerekirse sürdürülebilir bir turizm gelişmesini hedefleyen şehir plancılarının asıl meseleleri ne tür bir turizm gelişiminin turistleri çekeceğinden çok ne tür bir turizm gelişiminin mahalle sakinlerinin yere bağll lıklarını arttırabileceğini keşfetmek olmalıdır. Başka bir ifadeyle yer kimliği ve yere bağlılı̆̆ın güçlendirilmesi için mahalle sakinlerinin bilişsel yapısı ile uyumlu olabilecek yerel turizm faaliyetlerinin inşa edilmesini teminat altına almaları gerekmektedir. $\mathrm{Bu}$ tür çabalar, muhtemelen bireylerin mekanla kurdukları ilişkilerini ve dolayısıyla çevresel doyumunu arttırıcı bir rol oynayacaktır.

\section{KAYNAKÇA}

Altanlar A. (2015). Kültür Turizmini Geliştirme Kapasitesinin Ölçülmesinde Kavramsal Bir Model Ve Yöntem Denemesi: İstanbul, Boğaziçi Örneği (Basılmamış Doktora Tezi). İstanbul: Yıldız Teknik Üniversitesi Fen Bilimleri Enstitüsü, Şehir Planlama Programı.

Amasya Valiliği. (2020, 12 26). Sofular Projesi İle Şehrimize Yeni Bir Turizm Destinasyonu Kazandırılacak. http://www.amasya.gov.tr/: $\quad$ http://www.amasya.gov.tr/kadim-kentin-yeni-kultur-rotasi-sofular-projesi-ilesehrimize-yeni-bir-turizm-destinasyonu-kazandirilacak adresinden alındı.

Bolzoni M. (2013). What Tourists Ignore Ambivalences, Conflicts and Compromises In A Changing Neighbourhood. RC21 Conference 2013, Session 17: Resistance And Protest in Tge Toruist City. http://www.rc21.org/conferences/berlin2013/prog-17.php.

Bolzoni M. (2014). Turning To Leisure And Entertainment In Time Of Crisis. Atlantis, 10-14.

Bonaiuto M. Aiello M. Bonnes M. ve Ercolani A. (1999). Multidimentsional Perception Of Residential Environment Quality And Neighbourhood Attachment In The Urban Environment. Journal of Environmental Psychology, 19:331-352.

Brown B. Perkins D. D. ve Brown G. (2003). Place Attachment In A Revitalizing Neighborhood: Individual And Block Levels Of Analysis. Journal of Environmental Psychology, 259-271.

Chen C.Y. (2018). Influence Of Celebrity Involvement On Place Attachment: Role Of Destination Image In Film Tourism. Asia Pacific Journal of Tourism Research, 23 (1):1-14.

Chen N. ve Dwyer L. (2017). Residents' Place Satisfaction And Place Attachment On Destination Brand-Building Behaviors: Conceptual And Empirical Differentiation. Empirical Research Articles, 1-16.

Chen N. Dwyer L. ve Firth T. (2014). Effect of Dimensions Of Place Attachment On Residents' Word-of-Mouth Behavior. Tourism Geographies, 16(5):826-843.

Çokluk Ö. Şekercioğlu G. ve Büyüköztürk Ş. (2012). Sosyal Bilimler İ̧̧in Çok Değişkenli İstatistik: SPSS ve LISTER Uygulamaları. Pegem Akademi: Ankara.

Dwyer L. Chen N. ve Lee J. (2019). The Role Of Place Attachment In Tourism Research , Journal of Travel \& Tourism Marketing, 36(5):645-652.

DeCarlo, L. T. (1997). On the meaning and use of kurtosis. Psychological Methods, 2(3), 292307. https://doi.org/10.1037/1082-989X.2.3.292

Fried M. (2000). Continuities And Discontinuities of Place. Journal of Environmental Psychology, 193-205. 
Göregenli M (2010). Çevre Psikolojisi İnsan Mekan İlişkileri. İstanbul: Bilgi İletişim Grubu Yayıncılık Müzik Yapım ve Haber Ajansı LTD. ŞTí.

Göregenli M. Karakuş P. Özgen Kösten Y. E. ve Umuroğlu İ. (2014). Mahalleye Bağlllık Düzeyinin Kent Kimliği ile İlişkisi İçinde İncelenmesi. Türk Psikoloji Dergisi, 73-85.

Gu H. ve Ryan C. (2008). Place Attachment, Identity and Community Impacts Of Tourism- The Case of Beijing Hutong. Tourism Management, 39(4):637-647.

Guo Y. Zhang J. ve Zheng C. (2018). Catalyst Or Barrier? The Influence Of Place Attachment On Perceived Community Resilience In Tourism Destinations. Sustainability, 10 (7): 2347-2360.

Gursoy D. ve Rutherford D. (2004). Host Attıtudes Toward Tourism An İmproved Structural Model. Pergamon Annals of Tourism Research, 31(3):495-516.

Herna'ndez B. Hidalgo C. Salazar-Laplace E. ve Hess S. (2007). Place Attachment And Place Identity in Natives And Non-natives. Journal of Environmental Psychology, 27:310-319.

Hidalgo C. M. ve Hernandez B. (2001). Place Attachment: Conceptual And Empirical Questions. Journal of Environmental Psychology, 273-281.

Hopkins, K.D. ve Weeks, D.L. (1990), “Tests for Normality and Measures of Skewness and Kurtosis: Their Place in Research Reporting", Educational and Psychological Measurement, 50, 717-729.

Kyle G. Graefe A. ve Manning R. (2005). Testing The Dimentsionality of Place Attachment In Recreational Settings. Environment and Behavior, 37:153-177.

Lewicka M. (2005). Ways To Make People Active: The Role Of Place Attachment, Cultural Capita And Neighborhood Ties. Journal of Environmental Psychology, 381-395.

Mccool S. ve Martin S. (1994). Community Attachment and Attitudes Toward Tourism Development. Journal of Travel Research, 29-34.

Ramkissoon H. Graham Smith L. ve Weiler B. (2013). Testing the dimensionality of place attachment and its relationships with place satisfaction and pro-environmental behaviours: A structural equation modelling approach. Tourism Management, 36: 552-566.

Rollero C. \& Piccoli N. (2010). Place Attachment, Identification And Environment Perception: An Empirical Study. Journal of Environmental Psychology, 30:198-205.

Shen K. Geng C. ve Xinwei S. (2019). Antecedents Of Residents' Pro-tourism Behavioral Intention: Place Image, Place Attachment, and Attitude. Frontiers in Psychology, 1-12.

Stylidis D. (2017). Place Attachment, Perception Of Place and Residents' Support for Tourism Development. Tourism Planning \& Development, 1-23.

Tournois L. ve Djeric, G. (2019). Evaluating Urban Residents' Attitudes Towards Tourism development In Belgrade (Serbia). Curren Issues in Tourism, 1670-1678.

Turgut S. ve Özden P. (2006). Sürdürülebilir Ve Turizm Eksenli Bir Kentsel Dönüşüm Hedefine Doğru: Eminönü Tarihi Kent Merkezi. Planlama, 1: 49-62.

TÜİK. (2017, 08 10). Adrese Dayalı Nüfus Kayıt Bilgileri. Samsun. 
Türkün A. (2015). İstanbul'un Tarihi Konut Bölgelerinde Kentsel Dönüşüm: Tarlabaşı ve Fener-Balat- Ayvansayar Örnekleri. Z. Ahunbay, İ. Dinçer, \& D. Şahin içinde, Neoliberal Kent Politikalarl ve Fener-BalatAyvansaray Bir Koruma Mücadelesinin Öyküsü (ss. 133-182). İstanbul: Türkiye İş Bankası Kültür Yayınları.

Vorkin M. ve Reise H. (2001). Environmental Concern In A Local Context the Significance Of Place Attachment. Environment and Behavior, 33: 249-263.

Wang S. ve Chen J. (2015). The Influence Of Place Identity On Perceived Place Identity On Perceived. Annals of Toursim Research, 52:16-28.

Yılmaz Çakmak B. (2013). The Example Of A Re-Use in the Context Of Cultural Heritage Conservation, Hamdi Gültepe House. Artium, 1(1):1-12. 